\title{
Alpha-Thalassemia-2 and the Variability of Hematological Values in Children with Sickle Cell Anemia
}

\author{
C. ALTAY, ${ }^{(22)}$ M. E. GRAVELY, B. R. JOSEPH, AND D. F. WILLIAMS \\ Comprehensive Sickle Cell Center, Departments of Cell and Molecular Biology $y^{(19)}$ and Pediatrics, Medical College of \\ Georgia, Augusta, Georgia, USA
}

\section{Summary}

Seventy children homozygous for $\mathrm{Hb} S$ (SS) and their 111 heterozygous (AS) parents were evaluated through their erythrocytic indices, hemoglobin composition, and occasionally through in vitro $\mathrm{Hb}$ chain synthesis values.

Three groups of SS patients and of AS parents were identified based on differences in degree of microcytosis (MCV) and (degree of hypochromia $(\mathrm{MCH})$ values. The level of $\mathrm{Hb} \mathrm{S}$ in the $\mathrm{Hb} \mathrm{S}$ heterozygotes showed a trimodal distribution. Five SS patients had an $\alpha$-thalassemia homozygosity $\left(\alpha^{0} \alpha / \alpha^{0} \alpha ; \beta^{\mathrm{S}} / \beta^{\mathrm{S}}\right)$ which was characterized by a distinct microcytosis and hypochromia (MCV, $\leqq 70 \mathrm{fl} ; \mathrm{MCH}, \leqq 22 \mathrm{pg}$ ). Nine SS patients had an $\alpha$-thalassemia heterozygosity $\left(\alpha^{0} / \alpha / \alpha \alpha ; \beta^{\mathrm{S}} / \beta^{\mathrm{S}}\right)$ with an MCV value of 71 to 78 $\mathrm{fl}$, and an MCH value of 21.3 to $26.5 \mathrm{pg}$. Four AS parents had an $\alpha$-thalassemia-2 homozygosity with values of $\mathrm{MCV} \leqq 71 \mathrm{fl}$ and $\mathrm{MCH} \leqq 23.5$. The level of $\mathrm{Hb} \mathrm{S}$ was $<31 \%$. Thirty-nine AS parents had an $\alpha$-thalassemia- 2 heterozygosity characterized by an MCV value of 72 to $79 \mathrm{fl}$, an $\mathrm{MCH}$ value of 23.6 to 26.5, and a level of $\mathrm{Hb} \mathrm{S}$ ranging between 31.0 and $36.8 \%$.

The $\mathrm{Hb} \mathrm{A_{2 }}$ level in SS patients was significantly correlated with the RBC counts and the MCV and $\mathrm{MCH}(r=0.38,-0.52$, and -0.47 , respectively). Significant correlations in AS parents were also noted between the $\mathrm{MCV}, \mathrm{MCH}, \mathrm{RBC}$, and $\mathrm{Hb} \mathrm{S}$ percentages $(r=0.62,0.68$, and -0.49 , respectively).

Although the data are limited, the simultaneous occurrence of an $\alpha$-thal-2 homozygosity seems to decrease the level of $\mathrm{Hb} \mathrm{F}$ in sickle cell anemia. The presence of an $\alpha$-thal-2 heterozygosity or homozygosity together with an SS or AS condition resulted in identifiable hematologic phenotypes.

\section{Speculation}

The occurrence of microcytosis and hypochromia among SS patients in association with increased erythrocyte counts and $\mathrm{Hb}$ $A_{2}$ percentages indicates the concomitant presence of $\alpha$-thalassemia-provided $\beta$ chain deficiencies have been excluded through biosynthetic experiments or through family studies. The $\alpha$-thal-2 heterozygosity $\left(\alpha^{0} \alpha / \alpha \alpha ; \beta^{\mathrm{S}} / \beta^{\mathrm{S}}\right)$, which is associated with a mild $\alpha$ chain deficiency, results in a slight decrease of the degree of microcytosis and hypochromia values. On the other hand, the $\alpha$ thal-2 homozygosity $\left(\alpha^{0} \alpha / \alpha^{0} \alpha ; \beta^{\mathrm{S}} / \beta^{\mathrm{S}}\right)$ and perhaps also the $\alpha$ thal-1 heterozygosity $\left(\alpha^{0} \alpha^{0} / \alpha \alpha ; \beta^{\mathrm{s}} / \beta^{\mathrm{S}}\right)$, which are associated with a moderate $\alpha$ chain deficiency, result in a distinct microcytosis and hypochromia. The high incidence of $\alpha$-thal-2 among Black Americans requires careful consideration and may be more prevalent than an iron deficiency anemia in children with the SS and AS conditions.

The clinical and hematologic heterogeneity of sickle cell anemia (SS) and $\mathrm{Hb}$ S heterozygosity (AS) has been the subject of various studies $(2,5-9,14,16,17)$. These studies have indicated that the $\alpha$-thal-2 determinant, which is associated with a mild $\alpha$ chain deficiency due to the deletion of one of the four $\alpha$ chain genes, is rather prevalent in the Black population. The AS condition and an $\alpha$-thal-2 heterozygosity $\left(\alpha^{0} \alpha / \alpha \alpha ; \beta / \beta^{s}\right)$ or homozygosity $\left(\alpha^{0} \alpha /\right.$ $\left.\alpha^{0} \alpha ; \beta / \beta^{s}\right)$ often occur together. The two conditions can be identified through an evaluation of the proportions of $\mathrm{Hb} \mathrm{S}$, the degree of microcytosis and hypochromia values, and the $\alpha /$ non- $\alpha$ synthesis ratio, all of which are decreased when compared with similar data in $\mathrm{Hb} \mathrm{S}$ heterozygotes who lack $\alpha$-thalassemia $(\alpha \alpha / \alpha \alpha ; \beta /$ $\left.\beta^{s}\right)$.

These observations offer an additional approach for the diagnosis and evaluation of the $\alpha$-thalassemia conditions occurring among $\mathrm{Hb} \mathrm{S}$ homozygotes. The present study documents the occurrence of these two types of $\alpha$-thalassemia in an unselected group of SS children who attend the Pediatric Clinic of the Comprehensive Sickle Cell Center in Augusta, GA. The prevalence of $\alpha$-thal-2 in this group indicated by hematologic abnormalities was found to be higher than previously predicted. Correlation analyses of several hematological parameters provided details regarding the effect of the $\alpha$-thal-2 gene on these parameters.

\section{MATERIALS AND METHODS}

PATIENTS

Seventy SS children who attend the Pediatric Sickle Cell Clinic of the Center participated in this study. Their ages varied from 3 to 13.5 years; 36 were females, and 34 were males. Blood samples were collected by venipuncture with EDTA as anticoagulant. Informed consent was sought and obtained.

Grouping of the Cases. The patients and the parents were divided into three groups according to their $\mathrm{MCV}$ and $\mathrm{MCH}$ levels. Criteria for the divisions are as follows:

\section{Children with sickle cell anemia}

Group $1 \quad(\mathrm{MCV}) \geqq 80 \mathrm{fl} \quad(\mathrm{MCH})>26.5 \mathrm{pg}$ (presumed diagnosis: $\left.\alpha \alpha / \alpha \alpha ; \beta^{s /} / \beta^{s}\right)(21)$

Group 2 MCV 71 to $79 \mathrm{fl}$ MCH 23 to $26.5 \mathrm{pg}$ (presumed diagnosis: $\left.\alpha^{0} \alpha / \alpha \alpha ; \beta^{s} / \beta^{s}\right)$

Group $3 \mathrm{MCV} \leqq 70 \mathrm{fl} \quad \mathrm{MCH} \leqq 22 \mathrm{pg}$ (presumed diagnosis: $\alpha^{\prime \prime} \alpha /$ $\left.\alpha^{9} \alpha ; \beta^{s} / \beta^{s}\right)$

2. The AS parents were divided into three groups based on the level of $\mathrm{Hb} \mathrm{S}$, and the MCV and MCH values

\begin{tabular}{c|cc} 
Group 1 & $\mathrm{MCV} \geqq 80 \mathrm{fl}$ & $\mathrm{MCH} \geqq 27 \mathrm{pg}$ (presumed diagnosis: $\alpha \alpha /$ \\
Group 2 & $\mathrm{MCV} 72$ to $79 \mathrm{fl}$ & $\mathrm{MCH} 23.6$ to $26.5 \mathrm{pg} \quad \mathrm{Hb} \mathrm{S} 31.0$ to
\end{tabular}

(presumed diagnosis: $\alpha^{0} \alpha / \alpha \alpha ; \beta^{\mathrm{A}} / \beta^{\mathrm{s}}$ ) 
Group $3 \quad \mathrm{MCV} \leqq 71 \mathrm{fl} \quad \mathrm{MCH} \leqq 23.5 \mathrm{pg} \quad \mathrm{Hb} \mathrm{S}<31 \%$

(presumed diagnosis: $\alpha^{\prime \prime} \alpha / \alpha^{\prime \prime} \alpha ; \beta^{\mathrm{A}} / \beta^{\mathrm{s}}$ )

Homozygosity for $\mathrm{Hb} \mathrm{S}$ was documented by the absence of $\mathrm{Hb}$ $A$ in electrophoretic and chromatographic analyses. The presence of $\beta$-thalassemia in patients of groups 2 and 3 were excluded either by family study or by in vitro hemoglobin synthesis analysis. The parents of the SS patients classified in group 3 are included in group 2 (2a) because they are obligatory heterozygotes unless otherwise stated. Some of the data listed for these parents are divided into two groups based on the sex of the parent (Table 2).

\section{HEMATOLOGIC PROCEDURES}

Routine blood counts were obtained with a Coulter model S electronic cell counter. The hemoglobin composition was analyzed by starch gel electrophoresis at alkaline $\mathrm{pH}$ and by citrate agar electrophoresis at acid $\mathrm{pH}(10)$. The quantities of the different hemoglobins in red cell lysates were measured by chromatography on DEAE-cellulose using glycine- $\mathrm{KCN}-\mathrm{NaCl}$ developers (1). In vitro $\mathrm{Hb}$ chain synthesis followed procedures given in detail before (10). All incubations were for $5 \mathrm{~min}$ only, and globins prepared from lysed whole cells were analyzed.

Serum iron and transferrin levels were measured by conventional methods in all patients and parents which fell in groups 2 and 3. None of the subjects included in the study had an iron saturation less than $20 \%$.

The data were evaluated by Pearson's correlation test, partial correlation test, and by the multiple range test using Tukey HSD procedure (3).

\section{RESULTS}

Average values of the hematologic data, the percentages of the various $\mathrm{Hb}$ fractions, and the in vitro $\mathrm{Hb}$ chain synthesis data for the 70 SS patients are listed in Table 1. Table 2 summarizes similar data for $111 \mathrm{AS}$ parents. The correlations between some of the data are summarized in Table 3

Among the SS patients, the hematologic values were about the same for the two sexes. No differences were observed in regard to age except for percentages of $\mathrm{Hb} \mathrm{F}$ which showed a significant negative correlation (Table 3 ). The hemoglobin levels varied from 6.4 to $10.0 \mathrm{~g} / \mathrm{dl}$ and correlated with the percentage of $\mathrm{Hb} \mathrm{F}$ (Tables 1 and 3). Good correlations were obtained between the $\mathrm{MCV}$ and the $\mathrm{MCH}$ values, the $\mathrm{Hb} \mathrm{A}_{2}$ percentages and the erythrocyte counts, and with the $\mathrm{Hb} F$ levels and the MCV or MCH values, and the $\alpha /$ non- $\alpha$ ratios and the MCV values (Table 3). The application of partial correlation did not give any additional information.

The 56 patients in group 1 were assigned the $\alpha \alpha / \alpha \alpha ; \beta^{\mathrm{s}} / \beta^{\mathrm{s}}$ genic arrangement, i.e., they have a normal $\alpha$ chain genotype, whereas nine patients in group 2 were assigned the arrangement with three active $\alpha$ chain genes, or $\alpha^{0} \alpha / \alpha \alpha ; \beta^{S} / \beta^{S}$, due to an $\alpha$ thal-2 heterozygosity. The five patients forming group 3 were considered to have only two active $\alpha$ chain genes, or $\alpha^{0} \alpha / \alpha^{0} \alpha$; $\beta^{s} / \beta^{s}$, resulting from an $\alpha$-thal-2 homozygosity.

The presence of $\beta$-thalassemia was excluded in eight of 14 patients belonging to groups 2 and 3 (four of nine in group 2 and four of five in group 3) because all 16 parents were $\mathrm{Hb} \mathrm{S}$ heterozygotes. The mother of the other six patients had an AS trait, but the fathers were not available. In vitro synthesis analyses in these SS patients gave $\alpha /$ non- $\alpha$ ratios of 0.54 to 0.94 which excludes a $\beta$-thalassemia condition.

All five patients in group 3 had a much lower level of $\mathrm{Hb} F$ when compared to the SS patients in groups 1 and 2 (Table 1). Splenomegaly was noted in all five cases forming group 3 .

Sixty-eight of the $111 \mathrm{Hb} \mathrm{S}$ heterozygotes had no $\alpha$-thalassemia $\left(\alpha \alpha / \alpha \alpha ; \beta / \beta^{\mathrm{s}}\right)$ and are classified as group la (female) and lb (male). Group 2a included eight of the 10 parents of the five SS children of group 3 ; these parents belong to group 2 as obligatory heterozygotes for $\alpha$-thal-2 (Table 2). The father of one SS child in group 3 had a very low $\mathrm{MCV}, \mathrm{MCH}$, and percent $\mathrm{Hb} \mathrm{S}$ and is

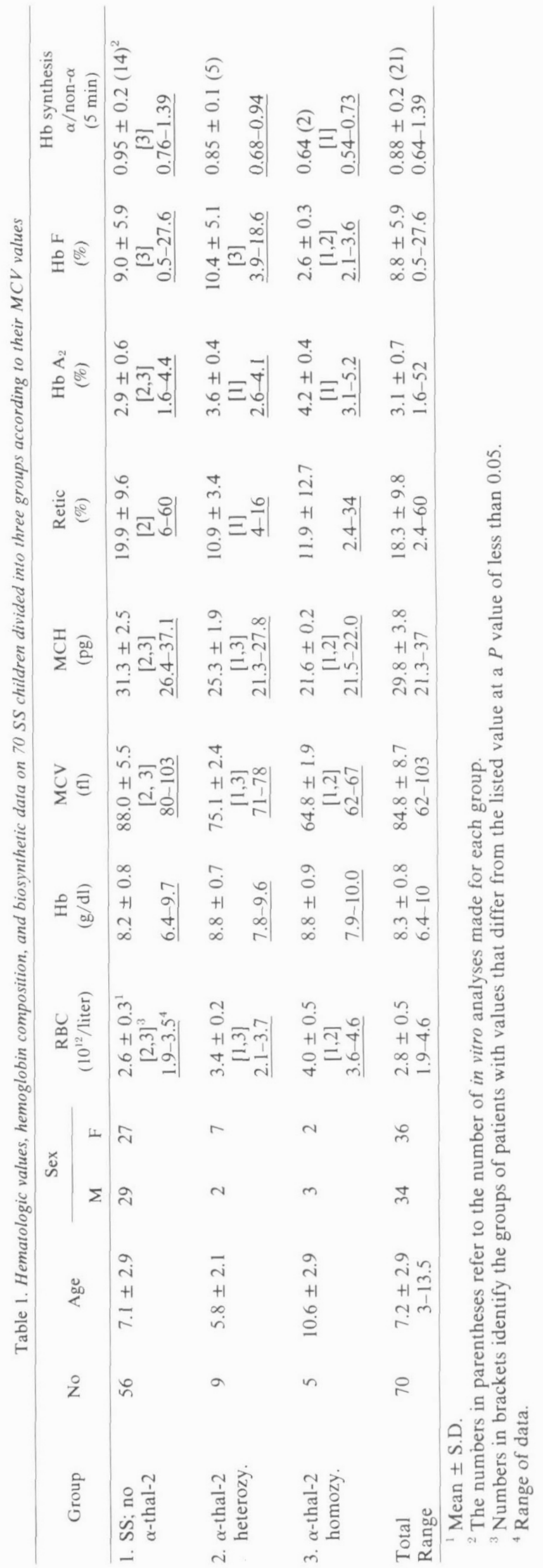


Table 2. Hematologic value and hemoglobin composition data of $111 \mathrm{Hb} S$ heterozygous parents of children with sickle cell anemia

\begin{tabular}{|c|c|c|c|c|c|c|c|c|c|}
\hline \multirow{2}{*}{ Group } & \multirow{2}{*}{ Age } & \multicolumn{2}{|c|}{ Sex } & \multirow{2}{*}{$\begin{array}{c}\mathrm{RBC} \\
\left(10^{12} / \text { liter }\right)\end{array}$} & \multirow{2}{*}{$\begin{array}{c}\mathrm{Hb} \\
(\mathrm{g} / \mathrm{dl})\end{array}$} & \multirow{2}{*}{$\begin{array}{l}\mathrm{MCV} \\
\text { (fl) }\end{array}$} & \multirow{2}{*}{$\begin{array}{l}\mathrm{MCH} \\
(\mathrm{pg})\end{array}$} & \multirow{2}{*}{$\begin{array}{c}\mathrm{Hb} \mathrm{A}_{2} \\
(\%)\end{array}$} & \multirow{2}{*}{$\begin{array}{l}\mathrm{Hb} \mathrm{S} \\
(\%)\end{array}$} \\
\hline & & M & $\mathrm{F}$ & & & & & & \\
\hline 1a. Mother without $\alpha$-thal-2 & $29.4 \pm 7.0^{1}$ & & 46 & $4.4 \pm 0.3$ & $13.0 \pm 0.9$ & $\begin{array}{c}86.0 \pm 4.4 \\
{[2,3]^{2}}\end{array}$ & $\begin{array}{l}29.1 \pm 1.3 \\
{[2,3]}\end{array}$ & $3.1 \pm 0.4$ & $\begin{array}{c}39.5 \pm 2.0 \\
{[2,3]}\end{array}$ \\
\hline b. Father without $\alpha$-thal-2 & $34.5 \pm 10.1$ & 22 & & $5.0 \pm 0.4$ & $14.9 \pm 1.2$ & $\begin{array}{c}87.1 \pm 4.3 \\
{[2,3]}\end{array}$ & $\begin{array}{c}29.9 \pm 1.5 \\
{[2,3]}\end{array}$ & $3.0 \pm 0.5$ & $\begin{array}{c}39.9 \pm 2.2 \\
{[2,3]}\end{array}$ \\
\hline $\begin{array}{l}\text { 2a. } \alpha \text {-thal-2 } \\
\quad \text { obligate heterozygotes }\end{array}$ & $34.3 \pm 14.0$ & 3 & 5 & $5.0 \pm 0.5$ & $14.0 \pm 1.6$ & $\begin{array}{c}80.2 \pm 4.4 \\
{[1,3]}\end{array}$ & $\begin{array}{c}26.5 \pm 1.1 \\
{[1,3]}\end{array}$ & $3.0 \pm 0.6$ & $\begin{array}{c}36.3 \pm 2.1 \\
{[1,3]}\end{array}$ \\
\hline Mother & $29.3 \pm 6.7$ & & & $4.8 \pm 0.4$ & $13.1 \pm 1.2$ & & & & \\
\hline Father & $37.2 \pm 17.1$ & & & $5.3 \pm 0.6$ & $15.4 \pm 1.0$ & & & & \\
\hline $\begin{array}{l}\text { b. } \alpha \text {-thal-2 } \\
\text { heterozygotes }\end{array}$ & $29.6 \pm 6.2$ & 10 & 21 & $4.9 \pm 0.5$ & $13.2 \pm 1.3$ & $\begin{array}{c}78.6 \pm 2.2 \\
{[1,3]}\end{array}$ & $\begin{array}{c}26.9 \pm 1.5 \\
{[1,3]}\end{array}$ & $3.3 \pm 0.6$ & $\begin{array}{c}35.6 \pm 2.3 \\
{[1,3]}\end{array}$ \\
\hline Mother & $29.7 \pm 5.1$ & & & $4.7 \pm 0.4$ & $12.6 \pm 1.0$ & & & & \\
\hline Father & $29.5 \pm 6.7$ & & & $5.3 \pm 0.4$ & $14.5 \pm 1.2$ & & & & \\
\hline 3. $\alpha$-thal-2 homozygotes & $33.3 \pm 10.6$ & 3 & 1 & $6.4 \pm 0.4$ & $14.7 \pm 1.3$ & $\begin{array}{c}68.8 \pm 2.2 \\
\quad[1,2]\end{array}$ & $\begin{array}{c}23.0 \pm 0.5^{\circ} \\
{[1,2]}\end{array}$ & $3.7 \pm 0.2$ & $\begin{array}{c}28.8 \pm 1.2 \\
{[1,2]}\end{array}$ \\
\hline Total & $31.0 \pm 8.5$ & 38 & 73 & $4.8 \pm 0.6$ & $13.6 \pm 1.4$ & $83.1 \pm 5.9$ & $28.2 \pm 2.1$ & $3.1 \pm 0.5$ & $37.9 \pm 3.3$ \\
\hline Range & $19-67$ & & & $3.7-6.6$ & $10.7-17.3$ & $66-96$ & $22.3-31.6$ & $1.8-4.3$ & $27.3-45$ \\
\hline
\end{tabular}

${ }^{\prime}$ Mean \pm S.D.

${ }^{2}$ Numbers between brackets identify the groups of patients with values that differ from the listed value at a $P$ value of less than 0.05 .

Table 3. Correlation of some of the data in children and in parents $^{1}$

$\begin{array}{lll}\text { Parameter } & r & P\end{array}$

Children

Ret $v s$.

$\begin{array}{lrr}\text { RBC } & -0.24 & 0.042 \\ \text { MCV } & 0.33 & 0.005 \\ \text { MCH } & 0.30 & 0.012\end{array}$

$\mathrm{Hb} \mathrm{A}(\%)$ vs.

$\mathrm{MCV}$

$\mathrm{MCH}$

$\mathrm{F}(\%)$

0.38

$-0.52$

$-0.47$

$-0.39$

$\mathrm{MCV} v s . \mathrm{MCH}$

0.70

0.001

0.001

0.001

0.001

0.001

$\mathrm{Hb} F(\%)$ vs.

Age

$\mathrm{Hb}$

Hb S (\%)

$-0.42$

0.35

$-0.96$

0.001

0.003

0.001

$\mathrm{Hb} \mathrm{S}(\%) v s$.

Age

0.36

$-0.39$

0.002

$\mathrm{Hb}$

0.48

0.001

$\alpha /$ non- $\alpha$ vs. MCV

0.025

Parents

Sex $v s$.

RBC

$\mathrm{Hb}$

PCV

$\mathrm{Hb} \mathrm{A}_{2}(\%) v s$.

Hb S (\%)

RBC

$-0.23$

0.24

0.002

0.017

$\mathrm{MCV}$ vs. $\mathrm{MCH}$

0.70

0.001

RBC vs,

$\mathrm{MCV}$

$\mathrm{MCH}$

$\mathrm{Hb} \mathrm{S}(\%)$

$-0.30$

$-0.28$

0.002

0.004

0.001

Hb S (\%) vs.

$$
\mathrm{MCV}
$$

$\mathrm{MCH}$

'Data not showing any significant correlation are omitted. included in parents group 3 with the $\alpha^{0} \alpha / \alpha^{0} \alpha ; \beta^{\mathrm{A}} / \beta^{\mathrm{S}}$ or $\alpha^{0} \alpha^{0} / \alpha \alpha$; $\beta^{\mathrm{A}} / \beta^{\mathrm{S}}$ conditions. However, examination of both paternal grandparents showed segregation of an $\alpha$-thal- 2 like condition excluding the presence of the $\alpha$-thal-1 gene in this family (these data will be published elsewhere). Thirty-one of 111 parents had $\alpha$-thal-2 heterozygosity (Table 2, group $2 \mathrm{~b}$ ). The four parents in group 3 had $\mathrm{MCV}$ values $\leqq 71 \mathrm{fl}$, MCH values $\leqq 23.5 \mathrm{pg}$, and $\mathrm{Hb}$ S values $<31 \%$, and were considered to be $\alpha$-thal-2 homozygotes $\left(\alpha^{0} \alpha / \alpha^{0} \alpha\right.$; $\left.\beta^{\mathrm{A}} / \beta^{\mathrm{s}}\right)$.

\section{DISCUSSION}

The data presented here confirm again that a significant number of SS patients and $\mathrm{Hb} \mathrm{S}$ heterozygotes have distinct hematologic features.

The hematologic observations in the five SS- $\alpha$-thal- 2 homozygotes suggest the following diagnostic criteria: $\mathrm{MCV} \leqq 70 \mathrm{fl}, \mathrm{MCH}$ $\leqq 22 \mathrm{pg}$, and $\mathrm{RBC} \geqq 3.5 \times 10^{12} /$ liter. Of interest are the high levels of $\mathrm{Hb} \mathrm{A_{2 }}$ and the low $\mathrm{Hb} F$ values. The elevated $\mathrm{Hb} \mathrm{A_{2 }}$ level among SS- $\alpha$-thal- 2 homozygotes $[4.2 \pm 0.4$ (S.D.); $n=5]$ probably results from a moderate $\alpha$ chain deficiency. In a previous study involying many $\mathrm{Hb} \mathrm{S}$ heterozygotes, a correlation between the assumed number of active $\alpha$ chain genes and the $\mathrm{Hb} \mathrm{A}$ values was also obtained $(8,14)$. It is much more difficult to decide if an $\alpha$-thal-2 heterozygosity is present, and a considerable overlap between the groups with three or four active $\alpha$ chain genes makes such a distinction in individual cases often impossible. These conclusions are similar to those reached previously in a smaller survey (6).

These observations imply that an elevated level of $\mathrm{Hb} \mathrm{A_{2 }}$ together with microcytosis in patients with sickle cell syndromes need not automatically identify the $\mathrm{S}-\beta^{0}$-thal condition except when data from a family study and/or in vitro $\mathrm{Hb}$ chain synthesis analyses suggest such a diagnosis. Although it was suggested that an $\alpha$ chain deficiency could promote the formation of $\mathrm{Hb} \mathrm{F}$ over $\mathrm{Hb} \mathrm{S}$ and $\mathrm{C}$ in $\mathrm{Hb} \mathrm{S}$ or $\mathrm{Hb} \mathrm{C}$ homozygotes (15-17), a recent physiochemical determination has shown that $\beta^{s}$ chains have a higher affinity than $\gamma$ chains for a limited supply of $\alpha$ chains (11). Indeed, despite great variation in the $\mathrm{Hb} \mathrm{F}$ level, the five $\alpha$-thal2 homozygotes had some of the lowest $\mathrm{Hb} \mathrm{F}$ percentages in this cohort. It should be noted that in a pediatric setting the $\mathrm{Hb} F$ levels ought to be evaluated together with the age of the patient (13); however, this age factor does not play a significant role in comparing the levels of $\mathrm{Hb} \mathrm{F}$ in our patients (Table 1).

The numbers of $\alpha$-thal- 2 heterozygotes $\left(\alpha^{0} \alpha / \alpha \alpha\right)$ among the 70 SS patients and among $111 \mathrm{Hb} \mathrm{S}$ heterozygotes suggest a rather high $\alpha$-thal- 2 frequency $(28 \%)$ in this population. This value is 
closer to that reported by Dozy et al. (4) obtained with gene mapping techniques than the figures obtained from cord blood studies (see, for instance, Ref. 8).

The presence of a palpable spleen in all five SS- $\alpha$-thal- 2 homozygotes is of special interest, and it appears that splenomegaly is another feature of the sickle cell anemia $\alpha$-thal- 2 homozygosity combination. This clinical finding can lead to misdiagnosis of the condition because this feature together with a high level of $\mathrm{Hb} \mathrm{A}_{2}$ and low indices are common observations in $\mathrm{Hb} \mathrm{S}-\beta^{0}$-thalassemia. Thus, family studies are critical for a differential diagnosis in these cases.

The high incidence of $\alpha$-thalassemia- 2 in Blacks should be kept in mind by physicians and a diagnosis of iron-deficiency anemia should not be based on low red cell indices only.

In a recent study, Powars et al. (12) indicated the absence of any correlation between hematological parameters and clinical severity of the disease. Although clinical evaluations of the patients are not included in this study, our personal observation of the SS patients indicates no evidence of differences in severity of the disease among various groups (18, 19).

\section{REFERENCES AND NOTES}

I. Abraham. E. C.. Reese. A.. Stallings. M.. and Huisman. T. H. J.: Separation of human hemoglobins by DEAE-cellulose chromatography using glycine- $\mathrm{KCN}$ $\mathrm{NaCl}$ developers. Hemoglobin. 1: 27 (1977).

2. Brittenham. G.. Lozoff. B.. Harris. J. W.. Mayson. S. M., Miller, A., and Huisman. T. H. J.: Sickle cell anemia and trait in southern India: further studies. Am. J. Hematol.. 6: 107 (1979)

3. Bruning. J. L.. and Kintz. B. L.: Computational Handbook of Statistics. Ed. 2 (Scott Foresman Co.. Glenview, IL. 1977).

4. Dozy. A. M.. Kan. Y. W.. Embury, S. H.. Mentzer, W. C., Lubin. B., Davis, J R.. Jr., and Koenig. H. M $: \alpha$-Globin gene organization in blacks precludes the severe form of $\alpha$-thalassemia. Nature (Lond.) 280: 605 (1979).

5. Felice. A. Abraham. E. C.. Miller. A.. Cope. N. Gravely. M.. and Huisman. T. H. J.: Post-translational control of human hemoglobin synthesis of $\mathrm{Hb} \mathrm{S}$. In: G. J. Brewer: pp. 131-154 (Alan R. Liss. New York. 1978).

6. Felice. A. E.. Webber. B. Miller. A. Mayson, S. M. Harris, H. F. Henson, J. B. Gravely, M. E., and Huisman. T. H. J.: The association of sickle cell anemia with heterozygous and homozygous $\alpha$-thalassemia-2: in vitro $\mathrm{Hb}$ chain synthesis. Am. J. Hematol.. 6: 91 (1979).

7. Honig, G. R., Koshy, M., Mason. R. G.. and Vida, L. N.: Sickle cell syndromes.
II. The sickle cell $\alpha$-thalassemia syndrome. J. Pediatr., 92: 556 (1978).

8. Huisman. T. H. J.: Trimodality in the percentages of $\beta$ chain variants in heterozygotes: The effect of the number of active $\mathrm{Hb}_{n}$ structural loci. Hemoglobin. I: 349 (1977).

9. Huisman. T. H. J.: Sickle cell anemia as a syndrome: a review of diagnostic features Am. J. Hematol. 6: 173 (1979).

10. Huisman. T. H. J., and Jonxis, J. H. P.: The Hemoglobinopathies, Techniques of Identification. (Marcel Dekker, New York. 1977).

11. Ogunmola. G. B.. Esan. G. J. F., and Falusi. A. G.: Hemoglobin chain recombination and the pattern of composition of hemoglobin S and D in heterozygotes. Acta Haematol.. 63: 94 (1980)

12 Powars, D. R. Schroeder, W. A. Weiss, J. N Chan, L. S and Azen. S. P. Lack of influence of fetal hemoglobin levels or erythrocyte indices on the severity of sickle cell anemia. J. Clin. Invest., 65: 732 (1980).

13. Rucknagel. D. L.. Hanash. S. H.. Sing, C. F.. Winter. W. P.. Whitten. C. F., and Prasad. A. S.: Age and sex effects on hemoglobin F in sickle cell anemia. In G. Stamatoyannopoulos, A. W. Nienhuis: Cellular and Molecular Regulation of Hemoglobin Switching. (Grune Stratton. New York. 1978).

14. Sewell. A.. Millard. D.. and Serjeant. G.: The interaction of alpha thalassemia with SS disease. In: G. J. Brewer: The Red Cell. pp. 93-102 (Alan R. Liss. New York. 1978)

15. Steinberg. M. H.: Haemoglobin $\mathrm{C} / \alpha$-thalassemia: haematological and biosynthetic studies. Br. J. Haematol., 30: 337 (1975).

16. Van Enk. A.. Lang. A.. White. J. M., and Lehmann. H.: Benign obstetric history in women with sickle cell anemia associated with $\alpha$-thalassemia. $\mathrm{Br}$. Med. J. 4: 524 (1972)

17. Weatherall, D. J.. Clegg. J. B., Blankson. J., and McNeil. J. R.: A new sickling disorder resulting from interaction of the genes for haemoglobins $\mathrm{S}$ and $\alpha$ thalassemia. Br. J. Haematol.. 17: 517 (1969).

18. The authors are grateful to Dr. T. H. J. Huisman for his encouragement and advice during the study, to Dr. A. E. Felice and R. N. Wrightstone for their help in preparation of the manuscript, and to members of the Computer Center for their assistance in the statistical analyses.

19. Contribution No, 0634 .

20. Seventy children homozygous for $\mathrm{Hb} \mathrm{S}$ and 111 of their AS parents were evaluated hematologically. The data indicated that the percentage of heterozygous $\alpha$-thal-2 condition is present in the amount of $28 \%$ and was responsible for some of the hematological variation, such as $\mathrm{MCH}$. MCV. RBC values. $\mathrm{Hb} \mathrm{A}$, and $\mathrm{Hb} \mathrm{S}$ observed in these populations.

21. The presence of four active $\alpha$ chain genes is assumed: $\alpha^{10}$ indicates that this $\alpha$ chain gene is absent or non-functional.

22. Requests for reprints should be addressed to: Dr. Cigdem Altay, Associate Professor. Department of Cell and Molecular Biology. School of Medicine. Medical College of Georgia, Augusta, GA 30901 (USA).

23. This research was supported by USPHS Research grant HLB 06158

24. Received for publication September 16, 1980.

25. Accepted for publication December 9, 1980. 